\title{
Characterization, Phylogenetic Analyses, and Pathogenicity of Colletotrichum Species on Morus alba in Sichuan Province, China
}

\author{
Longhai Xue, ${ }^{1,2}$ Lei Zhang, ${ }^{1}$ Xiao Xiang Yang, ${ }^{1}$ Xiaoqin Huang, ${ }^{1}$ Wenxian Wu, ${ }^{1}$ Xiquan Zhou, ${ }^{1}$ James F. White, ${ }^{3}$ \\ Yong Liu, ${ }^{1,}{ }^{+}$and Chunjie $\mathrm{Li}^{2, \dagger}$ \\ ${ }^{1}$ Institute of Plant Protection, Sichuan Academy of Agricultural Sciences, Chengdu 610066, P.R. China \\ ${ }^{2}$ State Key Laboratory of Grassland Agro-ecosystems, Key Laboratory of Grassland Livestock Industry Innovation, Ministry of \\ Agriculture and Rural Affairs, College of Pastoral Agriculture Science and Technology, Lanzhou University, Lanzhou, 730020, \\ P.R. China \\ ${ }^{3}$ Department of Plant Biology, Rutgers University, New Brunswick, NJ, U.S.A.
}

\begin{abstract}
Brown spot disease caused by Colletotrichum species was found on leaves of mulberry (Morus alba L.) in Dujiangyan, Sichuan Province, China. Fungal isolates from leaf lesions were identified as six Colletotrichum species based on morphological characteristics and DNA analysis of the combined sequences ITS, GAPDH, ACT, CHS-1, TUB2, and GS. These included Colle-

agent of mulberry anthracnose was $C$. fioriniae, causing typical brown necrotic spots or streaks, followed by $C$. brevisporum, $C$. karstii, and $C$. kahawae subsp. ciggaro, whereas the two other species $(C$. fructicola and $C$. cliviae) showed no pathogenicity to mulberry. This study is the first report of these species associated with mulberry in China.
\end{abstract} totrichum fioriniae, C. fructicola, C. cliviae, C. karstii, C. kahawae subsp. ciggaro, and C. brevisporum. Results showed that the most important causal
Keywords: fungi, mulberry, brown spot disease, anthracnose
Mulberry (Morus alba L.) is a woody tree belonging to the family Moraceae and is distributed widely in China (Song et al. 2009). Mulberry is increasingly becoming an important economic crop worldwide and is mainly cultivated for its nutritional fruits, silkworm feeding, medicine, and beverage production. The fruit of mulberry is widely used as a nutritious food (Chang et al. 2011); the leaves, root bark, and twigs have been used in Chinese medicine for a long time to treat many illnesses, such as fever and other human diseases, and to lower blood pressure (Jia et al. 1999). Because leaves of M. alba contain 1-deoxynojirimycin as a characteristic constituent (Singab et al. 2005; Tsuduki et al. 2013), the leaves are currently used in teas for health support (Fan et al. 2016). Mulberry leaves are also used as fodder for animals in the winter and spring seasons (Cai et al. 2019), and research has shown that mulberry feed could enhance milk yield in dairy animals (Dillard and German 2000).

Mulberry anthracnose is a common and widespread leaf disease. Leaves infected with Colletotrichum dematium display brown necrotic spots or streaks (Yoshida et al. 1995) from early summer to autumn (Yoshida and Shirata 1998). Accordingly, this disease limits the productivity and quality of leaves, thus directly resulting in significant loss of leaves for both silkworm feeding (Yoshida et al. 2002) and tea production. Yoshida and Shirata (1999) showed that C. dematium can overwinter in infected or latently infected leaves, which could be the primary infection sources in the following year. Therefore, it has been a major problem to control this disease in mulberry cultivation (Yoshida et al. 2002).

${ }^{\dagger}$ Corresponding authors: Y. Liu; liuyongdr@163.com and C. J. Li; chunjie@1zu.edu.cn

Funding: This work was supported by the Study on the Etiology of the Early Apple Wilt Disease (2017LWJJ-004), USDA-NIFA Multistate Project W3157, and the New Jersey Agricultural Experiment Station.

The author(s) declare no conflict of interest.

Accepted for publication 17 April 2019.

This article is in the public domain and not copyrightable. It may be freely reprinted with customary crediting of the source. The American Phytopathological Society, 2019.
However, there have been few studies on anthracnose of mulberry up to now. Anthracnose on the mulberry leaves caused by $C$. morifolium Hara and C. morina Hara was first reported by Hara (1925, 1954). Yoshida et al. (1995) isolated anthracnose fungi from diseased mulberry leaves in various areas of Japan and identified their species based on the taxonomy proposed by von Arx (1957); they showed that the most frequent species identified was $C$. dematium, which was found to be the most aggressive causal agent of the disease based on pathogenicity tests, followed by $C$. gloeosporioides and C. acutatum. Colletotrichum species also reported on mulberry were $C$. morina in Japan (Kobayashi 2007) and C. moricola in India (Mathur 1979). In China, anthracnose on mulberry was mainly owing to C. morifolium (Tai 1979; Tian 1981) and C. morium (Zhang et al. 2011), but Colletotrichum spp. associated with mulberry were not identified molecularly. Therefore, the purpose of this study was to accurately identify and determine Colletotrichum species causing mulberry anthracnose according to their morphology, DNA sequences, and pathogenicity, which would be crucial to control this disease effectively.

\section{Materials and Methods}

Sample collection and isolation. In 2016 and 2017, infected leaves of mulberry (M. alba) were collected from a mulberry orchard (about 15 ha in total, $30.81098^{\circ} \mathrm{N}, 103.69836^{\circ} \mathrm{W}$ ) in Dujiangyan city, Sichuan Province, China. Three pieces $\left(5 \times 5 \mathrm{~mm}^{2}\right)$ of leaf tissues at the border of lesions from each plant of 40 random plants were surface sterilized $(70 \%$ ethanol for $60 \mathrm{~s}, 5 \%$ commercial $\mathrm{NaClO}$ for $3 \mathrm{~min}$ ) and placed on potato dextrose agar (PDA) supplemented with $50 \mathrm{mg} /$ liter of ampicillin sodium salt and incubated at $25^{\circ} \mathrm{C}$. Fungal hyphae grown from the leaf tissues were picked up and transferred to fresh PDA within 2 to 8 days. Referring to the procedure described by Cai et al. (2009), single-spore isolates of each Colletotrichum isolate were obtained for the follow-up studies. All isolates were preliminarily identified by morphology and the internal transcribed spacer (ITS) and glyceraldehyde-3-phosphate dehydrogenase (GAPDH) sequences. The numbers of fungi were recorded, and the percentage of each Colletotrichum species was calculated.

Morphological and cultural characterization. Mycelial plugs $(6 \mathrm{~mm})$ of the single-spore cultures were transferred from the edge of the growing colonies to fresh PDA plates. The plates were then placed in an incubator (GXZ, Ningbo Jiangnan Instrument Co., 
Zhejiang, China) at $5,10,15,20,25,30$, and $35^{\circ} \mathrm{C}$ in the dark. Referring to the method of Han et al. (2016), colony diameters (five replicates) were measured after 5 days, and daily growth rate $=$ (colony diameter -6$) / 2 \mathrm{~mm}$. Colonies of all isolates except for group 4 produced pale orange conidia masses after 7 to 15 days; for group 4 isolates, they were first incubated at $25^{\circ} \mathrm{C}$ for 5 days, and then mycelia were wounded with a sterilized wire loop $(\mathrm{PDA}+\mathrm{W})$; orange conidia masses were produced on the edge of the wounds after 2 to 10 days. Appressoria were produced using a slide culture technique in which a $1-\mathrm{cm}^{2}$ square of a Colletotrichum culture on PDA was placed in an empty Petri dish, and a sterile cover slip was placed over the agar (Cai et al. 2009). After 7 days, the appressoria were observed on the underside of the cover slip. Microscopic preparations were made in sterile water and observed with a Nikon ECLIPSE Ti microscope (Nikon, Tokyo, Japan), with 30 measurements per each type of structure. Colony colors were rated according to the method of Rayner (1970). All relevant data were compared by Duncan's test $(P \leq$ 0.05) using IBM SPSS Statistics 19.0.

DNA extraction, PCR amplification, and DNA sequencing. Mycelia were scraped from the fresh colony using a sterile medicine spoon. Genomic DNA was extracted by using a Fungal DNA Kit (Omega Bio-Tek, Doraville, CA). The concentration of DNA was manually adjusted at $100 \mathrm{ng} / \mu \mathrm{l}$ after measurement by a Nanodrop 2000 spectrophotometer (Thermo Scientific). The rDNA-ITS region, partial $G A P D H$, calmodulin $(C A L)$, actin $(A C T)$, chitin synthase 1 (CHS-1), histone (HIS3), and $\beta$-tubulin (TUB2) genes were amplified by ITS-1F/ITS-4, GDF1/GDR1, CAL 228F/CAL 737R,
ACT-512F/ACT-783R, CHS-354R/CHS-79F, CYLH3F/CYLH3R, and $\mathrm{T} 1 / \mathrm{Bt}-2 \mathrm{~b}$, respectively (Damm et al. 2012b). The amplifications were performed in a T100TM Thermal Cycler (Bio-Rad, Hercules, CA) in a total volume of $20 \mu \mathrm{l}$ containing $1 \mu \mathrm{l}$ of genomic DNA, $1 \mu \mathrm{l}$ of each forward/reverse primer $(10 \mu \mathrm{M}), 10 \mu \mathrm{l}$ of I-5 $2 \times$ High-Fidelity Master Mix (MCLAB, South San Francisco, CA), and $7 \mu \mathrm{l}$ of sterile water. DNA sequencing was performed by Tsingke Biological Technology Co. (Chengdu, China).

Phylogenetic analysis. The combined ITS, GAPDH, ACT, CHS1 , and $T U B 2$ sequences were aligned using Clustal $\mathrm{X}$ as implemented in MEGA version 6 and manually adjusted to allow maximum sequence similarity. The aligned file was analyzed using the criteria of both neighbor-joining and maximum likelihood in MEGA version 6 (Tamura et al. 2013), respectively. Trees were decorated in Microsoft Office Word 2007.

Pathogenicity of Colletotrichum isolates. The single-spore strains of Colletotrichum were cultured at $25^{\circ} \mathrm{C}$ for 5 days, and then 4-mm PDA plugs were cut from the edge of fresh colonies for pathogenicity tests. Conidia were obtained by growing the isolates on PDA or PDA + W for 7 to 15 days as described above. The conidial suspension was adjusted to two concentrations of $1 \times 10^{6}$ and $1 \times 10^{9}$ conidia $/ \mathrm{ml}$ in sterile water with $0.01 \%$ (vol $/ \mathrm{vol}$ ) Tween 80 . Pathogenicity assays were performed on healthy and young leaves of detached mulberry twigs. Mulberry twigs were randomly divided into six groups, which were inoculated with six groups of isolates. For each isolate, 20 leaves on detached mulberry twigs were inoculated with and without wounding (Than et al. 2008). Nonwound
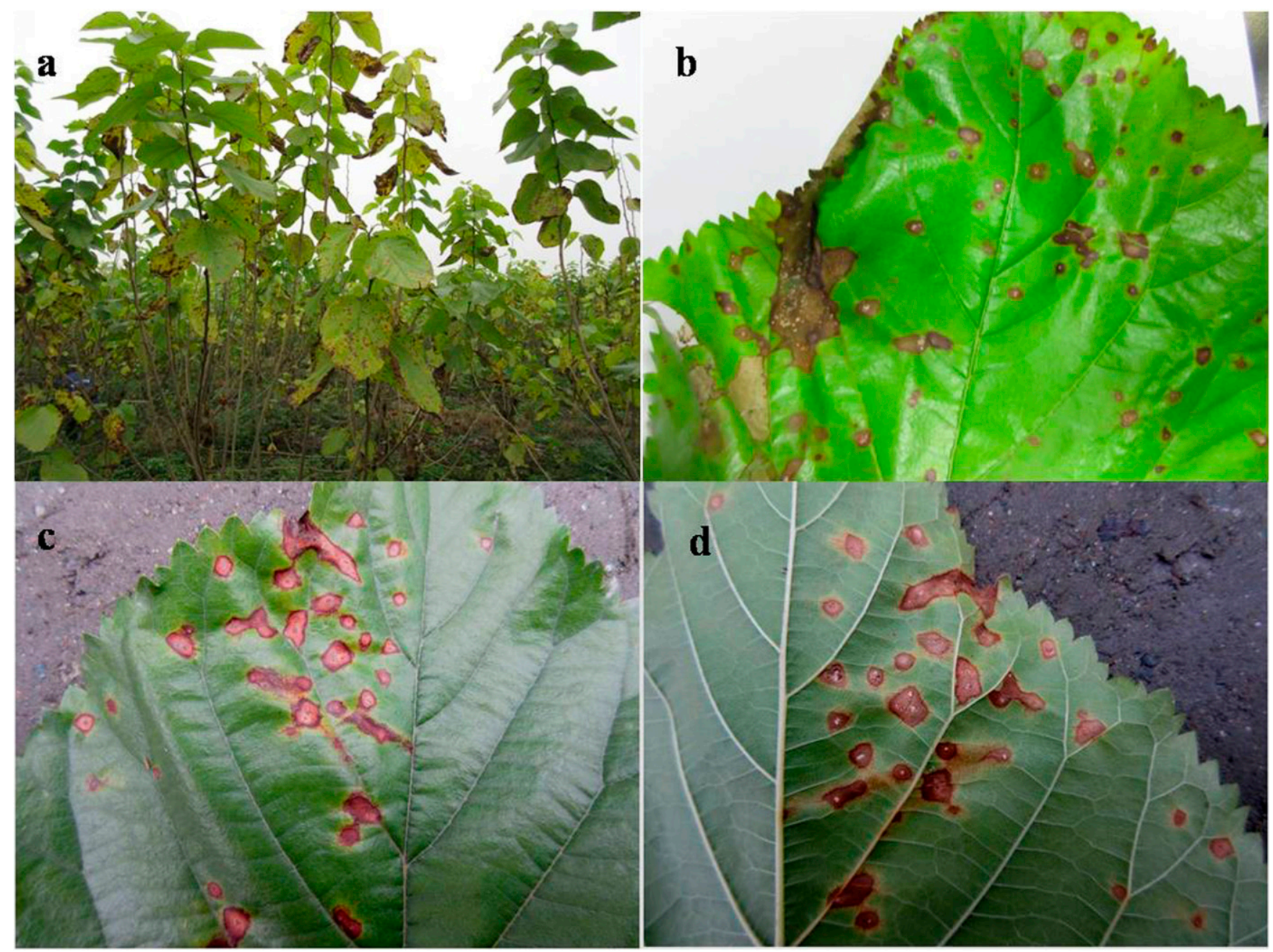

Fig. 1. Anthracnose on mulberry caused by Colletotrichum spp. under natural conditions: $\mathbf{a}$, infected mulberry plants; $\mathbf{b}$, symptoms under wet, humid conditions; and $\mathbf{c}$ and d, typical anthracnose symptoms. 
inoculation was performed by placing a $15-\mu l$ conidial suspension $\left(1 \times 10^{6}\right.$ or $1 \times 10^{9}$ conidia/ml) or 4 -mm PDA plugs onto the middle of the right side of the leaves. According with the inoculation method of Scandiani et al. (2011), wound inoculation involved pin-pricking the middle of the leaves (two sites per leaf along the longitudinal axis) and then placing PDA plugs (4-mm diameter) with the mycelium in contact with the wound. Plants inoculated with sterile water
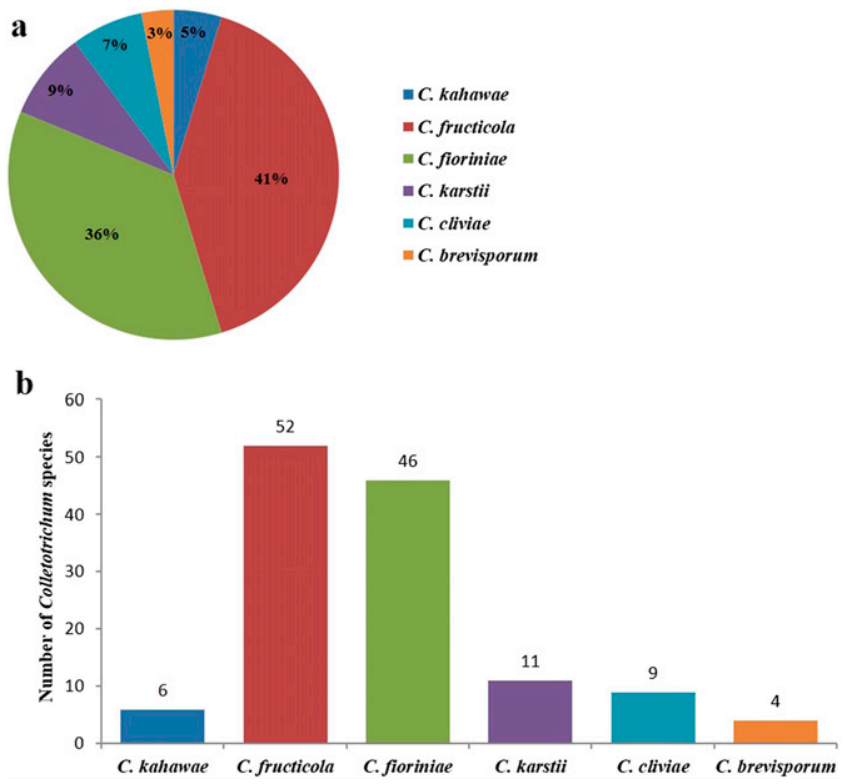

Fig. 2. Proportions of Colletotrichum species found on mulberry: a, percentage of isolates of each Colletotrichum species on mulberry; and $\mathbf{b}$, number of Colletotrichum species recovered from mulberry. suspension containing Tween 80 or 4-mm PDA plugs without the fungus were used as controls. After inoculation, the twigs were placed in transparent plastic boxes to maintain high relative humidity and maintained at $25^{\circ} \mathrm{C}$ in an incubator. Disease incidence (infected leaves) was assessed 10 days after inoculation, and the diameters of lesions were measured by the crossing method (width and length of lesions) to evaluate the virulence. To fulfill Koch's postulates, all fungal isolates included in the pathogenicity tests were reisolated from infected leaves to confirm their identity by molecular and morphological approaches as described above. The data of the lesion diameters were compared by Tukey's test $(P \leq 0.05)$ using IBM SPSS Statistics 19.0.

\section{Results}

Symptoms and separation rate of Colletotrichum species. Mulberry anthracnose was frequently observed in the mulberry orchard during 2016 and 2017. Symptoms on leaves developed on the middle and lower leaves of twigs from late June to the following January to February (when all the leaves dropped off). In the field, the leaves showed brown, necrotic, circular to irregular spots or streaks, and the orange masses of conidia were always visible on the abaxial leaf surface in the center of lesions (Fig. 1c and d). The symptoms initially appeared as small pale or red brown spots, which later became dark brown or tan, irregular or circular in shape, more or less sunken lesions. Gradually, the necrotic lesions enlarged, coalesced, and covered a large percentage of the leaf area, and eventually the leaves became yellow and then withered and died (Fig. 1a). Under wet, humid conditions, orange masses of conidia were always visible on both leaf surfaces in the center of lesions (Fig. 1b).

In total, 128 Colletotrichum isolates were obtained (Fig. 2a). Based on the high similarity of morphology as well as ITS and GAPDH sequences, C. fructicola (group 2) was the most common species, representing $40 \%$ of all Colletotrichum isolates, followed by C. fioriniae (group 3), C. karstii (group 4), C. cliviae (group 5), C. kahawae (group 1), and C. brevisporum (group 6), which accounted for $36,9,7,5$, and $3 \%$, respectively (Fig. 2 b).

Table 1. Morphological and cultural characteristics of Colletotrichum isolates from mulberry ${ }^{\mathrm{z}}$

\begin{tabular}{|c|c|c|c|c|c|c|c|}
\hline \multirow{2}{*}{$\begin{array}{l}\text { Species } \\
\text { (group) }\end{array}$} & \multirow[b]{2}{*}{ Colony characters } & \multicolumn{3}{|c|}{ Conidia } & \multicolumn{3}{|c|}{ Appressoria } \\
\hline & & Length $(\mu \mathrm{m})$ & Width $(\mu \mathrm{m})$ & Shape & Length $(\mu \mathrm{m})$ & Width $(\mu \mathrm{m})$ & Characters \\
\hline $\begin{array}{l}\text { C. kahawae } \\
\text { subsp. } \\
\text { ciggaro } \\
\text { (group 1) }\end{array}$ & $\begin{array}{l}\text { Gray to gray-brown with } \\
\text { numerous black spots } \\
\text { in reverse }\end{array}$ & $\begin{array}{c}14.82 \pm 3.55 \mathrm{~b} \\
7.5-18.9\end{array}$ & $\begin{array}{l}4.53 \pm 0.93 c \\
2.4-6.2\end{array}$ & Cylindrical & $\begin{array}{l}9.55 \pm 2.93 b \\
4.8-12.7\end{array}$ & $\begin{array}{l}5.33 \pm 1.81 \mathrm{~b} \\
3.2-8.8\end{array}$ & $\begin{array}{l}\text { Hyaline to light brown, } \\
\text { globose, ovate to } \\
\text { slightly irregular }\end{array}$ \\
\hline $\begin{array}{l}\text { C. fructicola } \\
\text { (group 2) }\end{array}$ & $\begin{array}{l}\text { Gray to dark gray with } \\
\text { visible conidial masses } \\
\text { in the center; reverse } \\
\text { greyish green with } \\
\text { white halos }\end{array}$ & $\begin{array}{c}13.50 \pm 1.91 \mathrm{c} \\
7.9-17.8\end{array}$ & $\begin{array}{l}4.66 \pm 0.60 \mathrm{bc} \\
3.5-6.3\end{array}$ & Cylindrical & $\begin{array}{l}9.78 \pm 2.13 b \\
7.2-13.8\end{array}$ & $\begin{array}{l}6.12 \pm 2.39 \mathrm{~b} \\
4.2-12.4\end{array}$ & $\begin{array}{l}\text { Brown to dark brown, } \\
\text { ovoid, clavate, and } \\
\text { slightly irregular to } \\
\text { irregular }\end{array}$ \\
\hline $\begin{array}{l}\text { C. fioriniae } \\
\text { (group 3) }\end{array}$ & $\begin{array}{l}\text { White to light pink; } \\
\text { reverse brownish pink } \\
\text { to vinaceous with a } \\
\text { few black spots }\end{array}$ & $\begin{array}{l}11.30 \pm 1.18 \mathrm{~d} \\
7.8-13.8\end{array}$ & $\begin{array}{l}3.84 \pm 0.34 \mathrm{~d} \\
3.3-4.8\end{array}$ & Fusiform & $\begin{array}{l}9.02 \pm 1.71 b c \\
6.3-11.2\end{array}$ & $\begin{array}{l}6.31 \pm 1.54 \mathrm{~b} \\
5.1-9.8\end{array}$ & $\begin{array}{l}\text { Brown to dark brown, } \\
\text { circular to clavate, and } \\
\text { lightly irregular to } \\
\text { irregular }\end{array}$ \\
\hline $\begin{array}{l}\text { C. karstii } \\
\text { (group 4) }\end{array}$ & $\begin{array}{l}\text { Grew to white with dark } \\
\text { conidiomata scattered } \\
\text { over the surface; } \\
\text { reverse colorless to } \\
\text { pale orange with some } \\
\text { dark spots }\end{array}$ & $\begin{array}{l}14.18 \pm 1.42 b c \\
10.8-17.2\end{array}$ & $\begin{array}{l}6.14 \pm 0.71 \mathrm{a} \\
4.5-7.6\end{array}$ & Cylindrical & $\begin{array}{l}7.23 \pm 1.30 \mathrm{c} \\
5.2-8.8\end{array}$ & $\begin{array}{l}5.71 \pm 1.45 \mathrm{~b} \\
3.8-8.4\end{array}$ & $\begin{array}{l}\text { Light brown to brown, } \\
\text { circular to clavate, and } \\
\text { lightly irregular to } \\
\text { irregular }\end{array}$ \\
\hline $\begin{array}{l}\text { C. cliviae } \\
\text { (group 5) }\end{array}$ & $\begin{array}{l}\text { Gray to dark gray; } \\
\text { reverse gray-yellow to } \\
\text { gray-black with some } \\
\text { black spots }\end{array}$ & $\begin{array}{l}12.02 \pm 1.72 \mathrm{~d} \\
8.7-14.8\end{array}$ & $\begin{array}{l}4.46 \pm 0.47 \mathrm{c} \\
3.6-5.2\end{array}$ & Cylindrical & $\cdots$ & $\ldots$ & $\cdots$ \\
\hline $\begin{array}{l}\text { C. brevisporum } \\
\text { (group 6) }\end{array}$ & $\begin{array}{l}\text { Gray to dark gray; } \\
\text { reverse gray-black } \\
\text { with little black spots }\end{array}$ & $\begin{array}{l}18.64 \pm 2.04 \mathrm{a} \\
14.0-21.3\end{array}$ & $\begin{array}{l}4.89 \pm 0.41 b \\
3.9-5.6\end{array}$ & Long cylindrical & $\begin{array}{l}14.36 \pm 2.40 \mathrm{a} \\
8.8-20.2\end{array}$ & $\begin{array}{l}7.67 \pm 1.04 \mathrm{a} \\
6.4-10.8\end{array}$ & $\begin{array}{l}\text { Brown to dark brown } \\
\text { with a light brown } \\
\text { guttule in the middle, } \\
\text { ovoid or slightly } \\
\text { irregular }\end{array}$ \\
\hline
\end{tabular}

${ }^{\mathrm{z}}$ Columns with the same letter do not differ significantly according with Duncan's test $(P \leq 0.05)$. 
Morphological and cultural characterization. Colletotrichum isolates were classified into six morphological groups according to morphological and cultural characteristics (Table 1). Significant differences in colony morphology were observed among these six groups of isolates identified when grown on PDA (Fig. 3). In total, three types of conidia were observed: cylindrical (observed in groups $1,2,4,5$ ), fusiform (group 3), and long cylindrical (group 6). Appressoria in groups 1 to 6 were brown and lightly irregular to irregular,

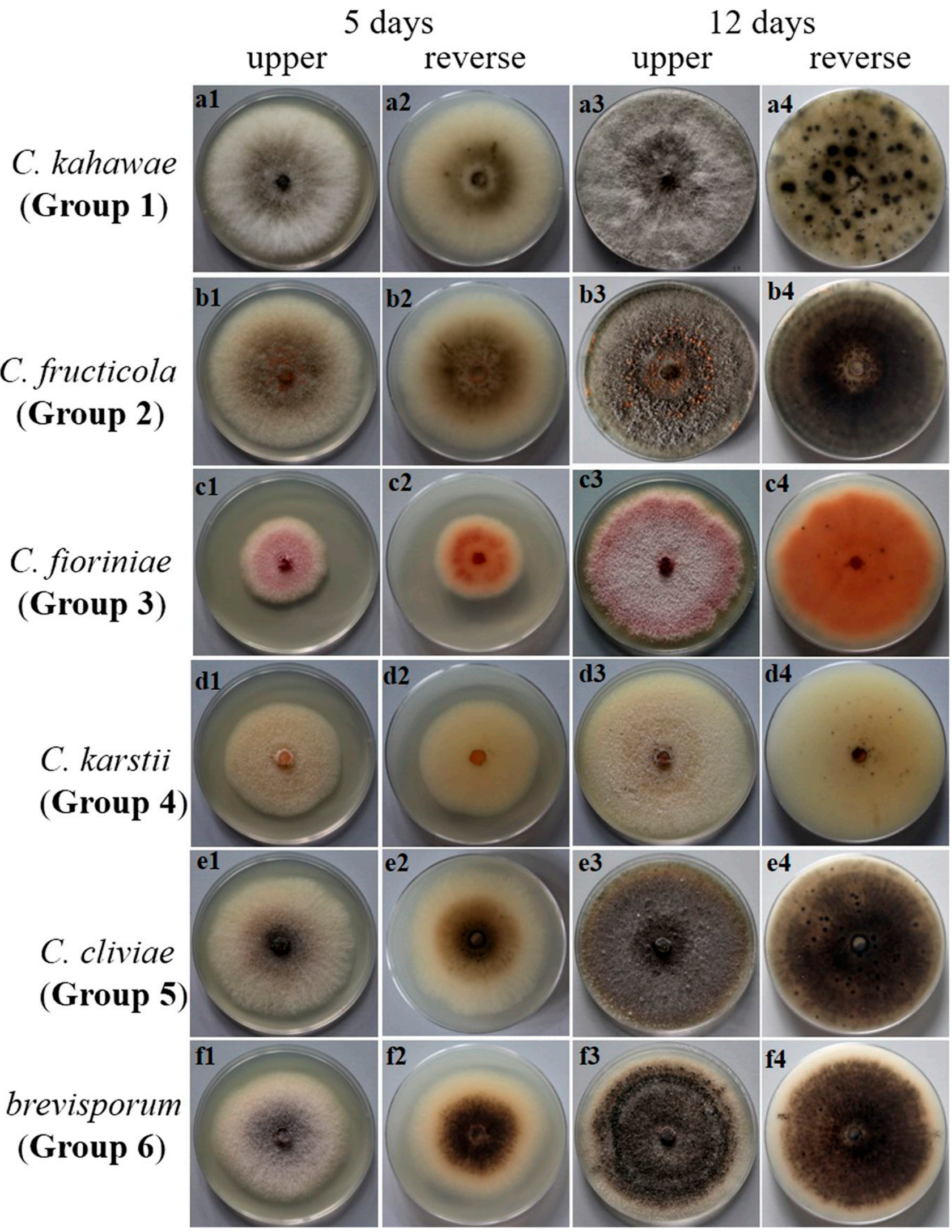

Fig. 3. Cultural traits of Colletotrichum species isolated from mulberry. 
and the sizes of appressoria were not different $(P \leq 0.05)$ among all the isolates except for group 6 . Coupled with the below phylogenetic analyses, the specific descriptions are as follows: Group 1 isolates were olive to gray with a white edge, and after 10 days, gray to gray-brown with numerous black spots in reverse. Conidia were hyaline, cylindrical, aseptate, and measured 7.5 to $18.9 \times 2.4$ to $6.2 \mu \mathrm{m}(x=14.82 \pm 3.55 \times 4.53 \pm 0.93, n=30)$. These characteristics were basically consistent with published descriptions of $C$. kahawae on Coffea arabica in Kenya (Waller et al. 1993) and Eruca sativa in Italy (Garibaldi et al. 2016). With the analysis of the glutamine synthetase $(G S)$ gene, group 1 isolates were finally identified as $C$. kahawae subsp. ciggaro. The colonies of group 2 were gray to dark gray, and they produced pale orange conidia masses in the center and in reverse greyish green with white halos after 12 days. Conidia were hyaline, aseptate, smooth-walled with a large guttule, cylindrical with obtuse to rounded ends, and measured 7.9 to $17.8 \times 3.5$ to $6.3 \mu \mathrm{m}(x=13.50 \pm 1.91 \times 4.66 \pm$ $0.60, n=30$ ). Compared with $C$. fructicola described by Prihastuti et al. (2009), for which conidial masses were not visible in the colony, group 2 showed visible conidial masses after 10 days. This species is similar to reports for C. fructicola on Citrus (Huang et al. 2013) and Annona (Costa et al. 2017). Group 3 isolates were light pink, and the reverse was brownish pink to vinaceous with a few black spots. Conidia were 7.8 to $13.8 \times 3.3$ to $4.8 \mu \mathrm{m}(x=$ $11.30 \pm 1.18 \times 3.84 \pm 0.34, n=30$ ), hyaline, aseptate, straight, and fusiform with acute ends. These characteristics were similar to the published descriptions of both $C$. fioriniae and C. acutatum that were reported by Damm et al. (2012a). Coupled with the analysis of multiple loci, group 3 isolates were identified as $C$. fioriniae. The characteristics of group 4 (Table 1) were highly similar to the descriptions of $C$. karstii (Damm et al. 2012b). Colonies produced by group 5 were gray to dark gray, and the reverse was gray-yellow to gray-black with some black spots. Conidia produced on PDA $+\mathrm{W}$ were hyaline, cylindrical, 8.7 to $14.8 \times 3.6$ to $5.2 \mu \mathrm{m}(x=12.02 \pm$
$1.72 \times 4.46 \pm 0.47, n=30$ ). Phylogenetic analysis showed that group 5 isolates were identified as $C$. cliviae. Group 6 isolates were first white, becoming gray to dark gray at the center with age, and in the reverse were gray-black with little black spots. Conidia measured 14.0 to $21.3 \times 3.9$ to $5.6 \mu \mathrm{m}(x=18.64 \pm 2.04 \times 4.89 \pm$ $0.41, n=30$ ) and were hyaline, aseptate with a large guttule at the center, and cylindrical with round ends. The sizes of conidia and appressoria were larger than the other five species (Table 1). These characters were consistent with the published descriptions of C. brevisporum on Lycium chinense (Paul et al. 2014) and Capsicum annuum (Liu et al. 2016a) in China.

Phylogenetic analyses. The sequences of single-spore strains and the reference sequences obtained from GenBank are shown in Table 2. The analysis of the individual $C A L, H I S 3$, and $G S$ sequences and combined ITS, GAPDH, ACT, CHS-1, and TUB2 sequences of our six isolates compared with sequences of 19 Colletotrichum species reported on different hosts from GenBank (Table 2) allowed us to allocate the isolates into the molecular groups of known Colletotrichum species. Phylogenetic analyses were performed by both neighbor-joining and maximum likelihood methods, and only one tree constructed by the maximum likelihood method is shown in Figure 4. In the maximum likelihood tree (six representative isolates were used for further molecular identification), S37 (from group 5) and two C. cliviae isolates (CSSK4 and CSSS1) (Yang et al. 2009) formed a subclade with $99 \%$ bootstrap support; S38 (group 6) and the $C$. brevisporum isolate COUFAL7300 (Bezerra et al. 2016) formed a subclade with $100 \%$ bootstrap support; S29 (group 4) and two C. karstii isolates (CBS 118401 and CBS 130235) (Damm et al. 2012b) formed a subclade with $100 \%$ bootstrap support; S22 (group 3) and three $C$. fioriniae isolates (CBS 235.49, CBS 490.92, and CBS 129948) (Damm et al. 2012a) formed a subclade with $91 \%$ bootstrap support; and S8 (group 1) and the extype C. kahawae isolate ICMP 18539 (Weir et al. 2012) formed a subclade with $100 \%$ bootstrap support. Furthermore, an

Table 2. GenBank accession numbers of isolates included in this study

\begin{tabular}{|c|c|c|c|c|c|}
\hline \multirow[b]{2}{*}{ Species } & \multirow[b]{2}{*}{ Accession } & \multirow[b]{2}{*}{ Host } & \multirow[b]{2}{*}{ Locality } & \multicolumn{2}{|c|}{ GenBank accessions $^{\mathrm{z}}$} \\
\hline & & & & ITS & GAPDH \\
\hline \multirow[t]{2}{*}{ Colletotrichum acutatum } & CBS 129919, CРC 13876 & Hoodia sp. & South Africa & JQ948370 & JQ948701 \\
\hline & CBS 369.73, NRCC 10081 & Lupinus angustifolius & New Zealand & JQ948350 & JQ948681 \\
\hline \multirow[t]{2}{*}{ C. alienum } & ICMP 12071 & Malus domestica & New Zealand & JX010251 & JX010028 \\
\hline & ICMP 18621 & Persea americana & New Zealand & JX010246 & JX009959 \\
\hline \multirow[t]{3}{*}{ C. kahawae subsp. ciggaro } & S8 & Morus alba & China & KY986888 & KY986894 \\
\hline & ICMP 18539 & Olea europaea & Australia & JX010230 & JX009966 \\
\hline & CBS 237.49, ICMP 17922 & Hypericum perforatum & Germany & JX010238 & JX010042 \\
\hline \multirow[t]{3}{*}{ C. fructicola } & S21 & Morus alba & China & KY986889 & KY986895 \\
\hline & ICMP 18613 & Limonium sinuatum & Israel & JX010167 & JX009998 \\
\hline & ICMP 18581, CBS 130416 & Coffea arabica & Thailand & JX010165 & JX010033 \\
\hline \multirow[t]{4}{*}{ C. fioriniae } & S22 & Morus alba & China & KY986890 & KY986896 \\
\hline & CBS 235.49 & Malus sp. & U.S.A. & JQ948325 & JQ948655 \\
\hline & CBS 490.92, АTCC 60260 & Solanum lycopersicum & New Zealand & JQ948326 & JQ948656 \\
\hline & CBS 129948, RB128 & Tulipa sp. & U.K. & JQ948344 & JQ948674 \\
\hline \multirow[t]{3}{*}{ C. karstii } & S29 & Morus alba & China & KY986891 & KY986897 \\
\hline & CBS 118401 & Pachira sp. & China & JQ005192 & JQ005279 \\
\hline & CBS 130235 & Gossypium hirsutum & Germany & JQ005190 & JQ005277 \\
\hline \multirow[t]{3}{*}{ C. cliviae } & S37 & Morus alba & China & KY986892 & KY986898 \\
\hline & CSSK4 & Clivia miniata & China & GQ485607 & GQ856756 \\
\hline & CSSS1 & Clivia miniata & China & GU109479 & GU085867 \\
\hline \multirow[t]{2}{*}{ C. brevisporum } & S38 & Morus alba & China & KY986893 & KY986899 \\
\hline & COUFAL7300 & Sechium edule & Brazil & KT285382 & KT285381 \\
\hline \multirow[t]{2}{*}{ C. nupharicola } & CBS 469.96, ICMP 17938 & Nuphar lutea subsp. polysepala & U.S.A. & JX010189 & JX009936 \\
\hline & CBS 470.96, ICMP 18187 & Nuphar lutea subsp. polysepala & U.S.A. & JX010187 & JX009972 \\
\hline Monilochaetes infuscans & CBS 869.96 & Ipomoea batatas & South Africa & JQ005780 & JX546612 \\
\hline
\end{tabular}

(Continued on next page)

\footnotetext{
${ }^{\mathrm{z}}$ ITS = internal transcribed spacers 1 and 2 together with 5.8S nrDNA; $G A P D H=$ partial glyceraldehyde-3-phosphate dehydrogenase gene; $A C T=$ partial actin gene; $C A L=$ partial calmodulin gene; $C H S-1=$ partial chitin synthase 1 gene; $H I S 3=$ histone3; $T U B 2=$ partial $\beta$-tubulin gene; and $G S=$ glutamine synthetase . Sequences generated in this study are indicated in bold.
} 
analysis of the $G S$ gene sequences indicated that isolate S8 belonged to C. kahawae subsp. ciggaro (Weir et al. 2012).

Effect of temperature on mycelial growth. The optimum temperature for growth of all species was $25^{\circ} \mathrm{C}$ (Table 3 ). The six species were easily differentiated at 20 and $25^{\circ} \mathrm{C}$. Group 1 had a significantly higher growth rate than the other five groups $(P \leq 0.05)$ at temperatures less than or equal $25^{\circ} \mathrm{C}$ but was sensitive to higher temperatures $\left(30^{\circ} \mathrm{C}\right)$, and no mycelial growth was observed at $35^{\circ} \mathrm{C}$. Relatively, C. brevisporum (group 6) was tolerant to high temperatures $\left(30,35^{\circ} \mathrm{C}\right)$, and its average growth rate was still $14.0 \mathrm{~mm} / 5$ days at $35^{\circ} \mathrm{C}$. Additionally, group 1 (C. kahawae subsp. ciggaro) was the most tolerant to low temperatures $\left(5,10^{\circ} \mathrm{C}\right)$, followed by $C$. fioriniae (group 3) and C. karstii (group 4), whereas no mycelial growth of group 2 (C. fructicola), group 5 (C. cliviae), and group 6 (C. brevisporum) was observed at $5^{\circ} \mathrm{C}$.

Pathogenicity. Pathogenicity tests showed that $C$. fioriniae was the most aggressive species, C. karstii, C. kahawae subsp. ciggaro, and C. brevisporum were weak pathogens, and C. fructicola and $C$. cliviae could not infect detached mulberry leaves (Table 4). Ten days after wounded or nonwounded inoculation, distinct water-soaked, brown or dark necrotic spots or streaks developed (Fig. 5). No symptoms developed on the corresponding controls. The symptoms caused by $C$. fioriniae developed brown necrotic spots after 10 days, which were similar to those that occur under natural conditions in the field (Fig. 5a). Only in the inoculation series using mycelial plugs of group 1, C. kahawae subsp. ciggaro showed weak pathogenicity on the intact and punctured mulberry leaves, respectively (Fig. 5h and i). Obviously, under the highconcentration conidial suspension $\left(1 \times 10^{9}\right.$ conidia/ml $)$ and wounded plants inoculated with PDA plugs conditions, $C$. karstii (group 4) produced lesions (Fig. 5d to g). When nonwounded plants were inoculated by group $6($ C. brevisporum) with $1 \times$ $10^{6}$ conidia/ml, few symptoms developed; however, when inoculated with $1 \times 10^{9}$ conidia/ml, up to $43 \%$ of the nonwounded leaves developed dark necrotic lesions (Fig. 5c); wounded and nonwounded plants inoculated with noncolonized PDA plugs remained nonsymptomatic. The Colletotrichum species were reisolated from the symptomatic leaves, and their identification was confirmed by morphology and molecular assays as described above.

\section{Discussion}

In the past few decades, anthracnose on mulberry ( $M$. alba) has been mainly attributed to $C$. dematium (Babu et al. 2008; Yoshida et al. 1995). So far, Colletotrichum species on mulberry have been only identified by using morphological characteristics (Tai 1979; Tian 1981; Yoshida et al. 1995; Zhang et al. 2011). However, many investigations have shown that it is difficult to accurately identify Colletotrichum species only by morphological and cultural features (Baroncelli et al. 2015; Cai et al. 2009; Cannon et al. 2000, 2012; Damm et al. 2009; Faedda et al. 2011). Therefore, phylogenetic analysis is indispensable for the identification of Colletotrichum species (Cai et al. 2009, 2011). This is the first time that Colletotrichum species on mulberry have been identified by both morphological data and sequence analysis of multiple loci. Accordingly, 128 isolates were accurately identified as $C$. kahawae subsp. ciggaro (six strains), C. fructicola (52 strains), C. fioriniae (46 strains), C. karstii (11 strains), C. cliviae (nine strains), and C. brevisporum (four strains). None of these species was previously reported on mulberry in China.

In recent years, $C$. fioriniae has been widely reported in China as a leaf spot pathogen in Cinnamomum subavenium (Sun et al. 2012), Ficus virens (Xue et al. 2017), and Juglans regia (Zhu et al. 2015); and as a fruit rot pathogen in Capsicum annuum and Capsicum spp. (Diao et al. 2017), Citrus spp. (Chen et al. 2017), and Lycium barbarum (Liu et al. 2016b). C. kahawae was recorded on chili peppers in China (Diao et al. 2017), and it was further identified as C. kahawae subsp. ciggaro by analyzing the $G S$ gene in this study.

Table 2. (Continued from preceding page)

\begin{tabular}{|c|c|c|c|c|c|c|}
\hline \multicolumn{6}{|c|}{ GenBank accessions $^{\mathrm{z}}$} & \multirow[b]{2}{*}{ References } \\
\hline$A C T$ & $C A L$ & CHS-1 & HIS3 & $T U B 2$ & $G S$ & \\
\hline JQ949691 & $\ldots$ & JQ949031 & JQ949361 & JQ950021 & $\ldots$ & Damm et al. (2012a) \\
\hline JQ949671 & $\ldots$ & JQ949011 & JQ949341 & JQ950001 & $\ldots$ & Damm et al. (2012a) \\
\hline JX009572 & JX009654 & JX009882 & $\ldots$ & JX010411 & JX010101 & Weir et al. (2012) \\
\hline JX009552 & JX009657 & JX009755 & $\ldots$ & JX010386 & JX010075 & Weir et al. (2012) \\
\hline KY986900 & KY986906 & KY986912 & MF033876 & MF033882 & MK585939 & This study \\
\hline JX009523 & JX009635 & JX009800 & $\ldots$ & JX010434 & JX010132 & Weir et al. (2012) \\
\hline JX009450 & JX009636 & JX009840 & $\ldots$ & JX010432 & JX010120 & Weir et al. (2012) \\
\hline KY986901 & KY986907 & KY986913 & MF033877 & MF033883 & MK585940 & This study \\
\hline JX009491 & JX009675 & JX009772 & $\ldots$ & JX010388 & JX010077 & Weir et al. (2012) \\
\hline FJ907426 & FJ917508 & JX009866 & $\ldots$ & JX010405 & JX010095 & Weir et al. (2012) \\
\hline KY986902 & KY986908 & KY986914 & MF033878 & MF033884 & MK585941 & This study \\
\hline JQ949646 & $\ldots$ & JQ948986 & JQ949316 & JQ949976 & $\ldots$ & Damm et al. (2012a) \\
\hline JQ949647 & $\ldots$ & JQ948987 & JQ949317 & JQ949977 & $\ldots$ & Damm et al. (2012a) \\
\hline JQ949665 & $\ldots$ & JQ949005 & JQ949335 & JQ949995 & $\ldots$ & Damm et al. (2012a) \\
\hline KY986903 & KY986909 & KY986915 & MF033879 & MF033885 & MK585942 & This study \\
\hline JQ005540 & JQ005713 & JQ005366 & JQ005453 & JQ005626 & $\ldots$ & Damm et al. (2012b) \\
\hline JQ005538 & JQ005711 & JQ005364 & JQ005451 & JQ005624 & $\ldots$ & Damm et al. (2012b) \\
\hline KY986904 & KY986910 & KY986916 & MF033880 & MF033886 & MK585943 & This study \\
\hline GQ856777 & GQ849464 & GQ856722 & $\ldots$ & GQ849440 & $\ldots$ & Yang et al. (2009) \\
\hline GU085861 & GU085863 & GU085865 & $\ldots$ & GU085869 & $\ldots$ & Yang et al. (2009) \\
\hline KY986905 & KY986911 & KY986917 & MF033881 & MF033887 & $\ldots$ & This study \\
\hline KT285378 & KT285379 & KT285380 & $\ldots$ & KT285383 & $\ldots$ & Bezerra et al. (2016) \\
\hline JX009486 & JX009661 & JX009834 & $\ldots$ & JX010397 & JX010087 & Weir et al. (2012) \\
\hline JX009437 & JX009663 & JX009835 & $\ldots$ & JX010398 & JX010088 & Weir et al. (2012) \\
\hline JQ005843 & $\ldots$ & JQ005801 & JQ005822 & JQ005864 & $\ldots$ & O'Connell et al. (2012) \\
\hline
\end{tabular}


C. kahawae subsp. ciggaro has been widely reported in many countries, including Australia, Brazil, Germany, New Zealand, South Africa, the United States, Colombia, Italy, Portugal, and Spain (Afanador-Kafuri et al. 2014; Liu et al. 2013; Schena et al. 2014; Weir et al. 2012). C. brevisporum has been reported on Citrus medica (Jayawardena et al. 2016; Peng et al. 2012) and Passiflora edulis (Du et al. 2017) from China. C. karstii was recorded as an endophyte from Bletilla ochracea (Tao et al. 2013) and as a pathogen on Citrus spp. (Huang et al. 2013), Hevea brasiliensis (Cai et al. 2016), Stylosanthes guianensis (Jia et al. 2017), and Nandina domestica (Li et al. 2018) in China. C. fructicola has been reported as an endophyte of several plants in Central America (Rojas et al. 2010). In this research, C. fructicola was the most prevalent species, but it showed no pathogenicity to mulberry leaves. In addition, although $C$. cliviae was recently reported to cause anthracnose on Glycine max (Barbieri et al. 2017), Capsicum spp. (Saini et al. 2017), and Zamioculcas zamiifolia (Zhou and Li 2017), our studies showed that $C$. cliviae was not pathogenic to mulberry leaves. This is the first report of two Colletotrichum species as leaf endophytes in mulberry.

Temperature is a primary factor that affects epidemics of plant disease (Bonde et al. 2012). The maximum growth temperature is also an important biological feature and widely used to characterize microorganisms (Damm et al. 2012a, 2012b; Prihastuti et al. 2009; Weir et al. 2012). In this study, temperature data showed that each species had a stable and distinguishable maximum temperature, which may be useful to distinguish Colletotrichum species on mulberry. On the other hand, these data may also provide useful information for the effective management of this disease in the future.

According to both the field and indoor inoculation symptoms, $C$. fioriniae forms typical lesions on mulberry leaves, but no clear lesions caused by C. karstii, C. kahawae subsp. ciggaro, and C. brevisporum were observed. $C$. fioriniae is the most important causal agent of mulberry leaf anthracnose, whereas $C$. karstii, C. kahawae subsp. ciggaro, and C. brevisporum showed a low pathogenicity to leaves.

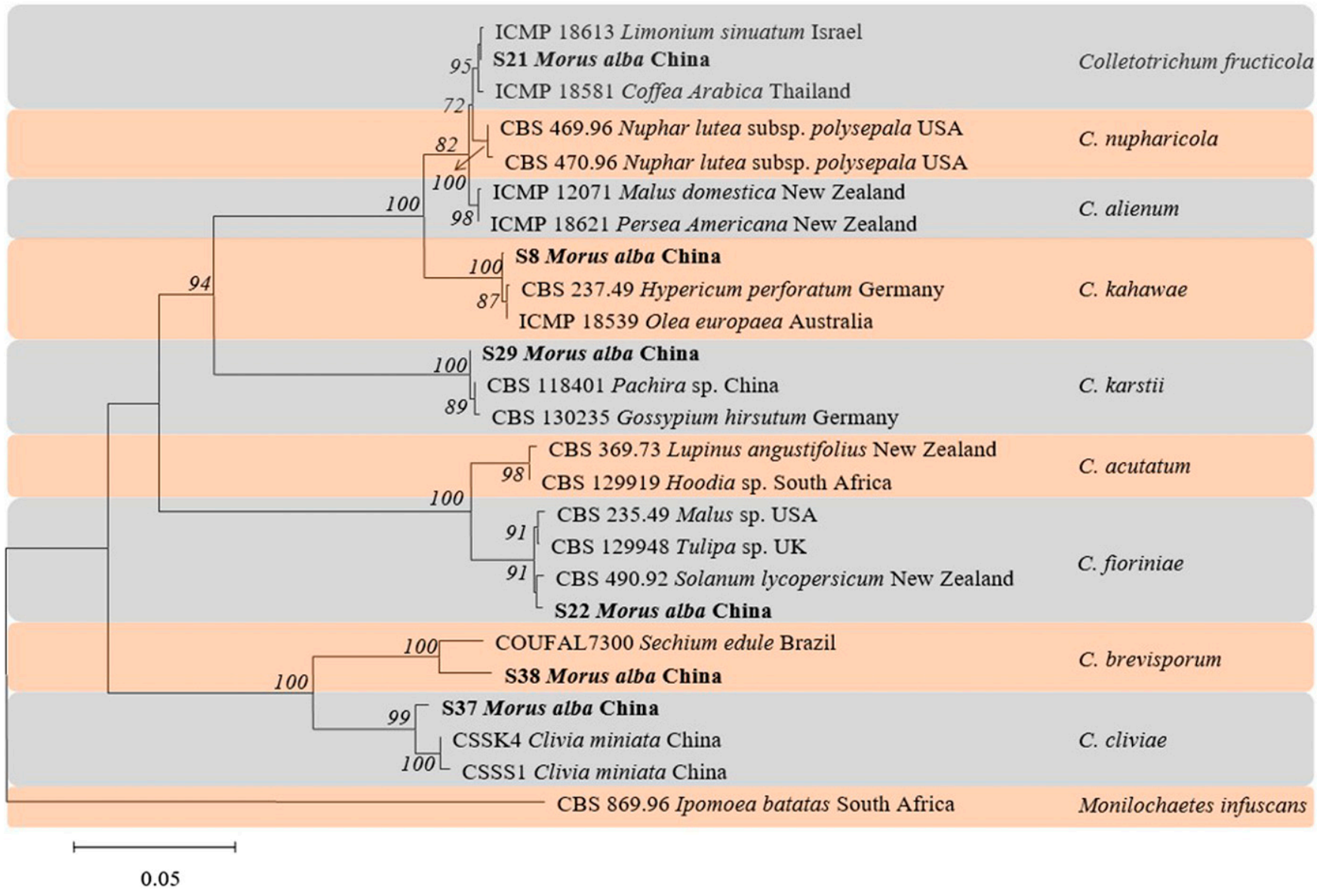

Fig. 4. Phylogram generated from maximum likelihood analysis based on alignment of ITS, GAPDH, ACT, CHS-1, and TUB2. Bootstrap values (1,000 replicates) above $70 \%$ are shown at the nodes. Host and country of origin are listed next to the isolate numbers. Isolates obtained in this study are shown in bold. Monilochaetes infuscans (CBS 869.96$)$ is used as an outgroup.

Table 3. Growth rate ( $\mathrm{mm} / 5$ days) of Colletotrichum isolates from mulberry cultured on PDA at different temperatures ${ }^{\mathrm{z}}$

\begin{tabular}{|c|c|c|c|c|c|c|c|}
\hline Species (group) & $5^{\circ} \mathrm{C}$ & $10^{\circ} \mathrm{C}$ & $15^{\circ} \mathrm{C}$ & $20^{\circ} \mathrm{C}$ & $25^{\circ} \mathrm{C}$ & $30^{\circ} \mathrm{C}$ & $35^{\circ} \mathrm{C}$ \\
\hline C. kahawae subsp. ciggaro (group 1) & $1.6 \pm 0.3 \mathrm{a}$ & $5.4 \pm 0.7 \mathrm{a}$ & $16.0 \pm 0.3 \mathrm{a}$ & $27.7 \pm 0.6 \mathrm{a}$ & $35.8 \pm 0.7 \mathrm{a}$ & $7.0 \pm 0.6 \mathrm{e}$ & $0 \mathrm{e}$ \\
\hline C. fructicola (group 2) & $0 \mathrm{c}$ & $2.4 \pm 0.5 \mathrm{c}$ & $11.4 \pm 0.7 \mathrm{c}$ & $24.1 \pm 0.7 b$ & $34.3 \pm 0.5 \mathrm{~b}$ & $20.1 \pm 0.7 \mathrm{~b}$ & $3.7 \pm 0.3 \mathrm{~b}$ \\
\hline C. fioriniae (group 3) & $1.2 \pm 0.6 \mathrm{~b}$ & $2.5 \pm 0.2 \mathrm{c}$ & $8.9 \pm 0.5 \mathrm{~d}$ & $15.6 \pm 0.4 \mathrm{f}$ & $19.2 \pm 0.3 \mathrm{f}$ & $6.2 \pm 0.3 \mathrm{~d}$ & $1.6 \pm 0.2 \mathrm{~d}$ \\
\hline C. karstii (group 4) & $0.8 \pm 0.3 \mathrm{~b}$ & $2.5 \pm 0.5 \mathrm{c}$ & $9.6 \pm 0.2 \mathrm{~d}$ & $18.3 \pm 0.3 \mathrm{e}$ & $25.1 \pm 0.5 \mathrm{e}$ & $14.1 \pm 0.3 \mathrm{c}$ & $1.5 \pm 0.3 \mathrm{~d}$ \\
\hline C. cliviae (group 5) & $0 \mathrm{c}$ & $2.7 \pm 0.9 b c$ & $13.0 \pm 1.0 \mathrm{~b}$ & $22.8 \pm 0.4 \mathrm{c}$ & $32.9 \pm 0.4 \mathrm{c}$ & $20.0 \pm 0.4 b$ & $3.1 \pm 0.1 \mathrm{c}$ \\
\hline C. brevisporum (group 6) & $0 \mathrm{c}$ & $3.6 \pm 0.5 b$ & $13.3 \pm 0.3 b$ & $21.8 \pm 0.5 \mathrm{~d}$ & $30.2 \pm 0.4 \mathrm{~d}$ & $29.7 \pm 0.1 \mathrm{a}$ & $14.0 \pm 0.2 \mathrm{a}$ \\
\hline
\end{tabular}

${ }^{\mathrm{z}}$ Columns with the same letter do not differ significantly according with Duncan's test $(P \leq 0.05)$. 
Table 4. Pathogenicity of Colletotrichum isolates on leaves of detached twigs, 10 days after wound and nonwound inoculation ${ }^{\mathrm{w}}$

\begin{tabular}{|c|c|c|c|c|c|c|c|c|}
\hline \multirow[b]{4}{*}{ Species } & \multicolumn{4}{|c|}{ Infected leaves $(\%)$} & \multicolumn{4}{|c|}{ Lesion diameter (mm) } \\
\hline & \multicolumn{2}{|c|}{ Conidial suspension } & & & \multicolumn{2}{|c|}{ Conidial suspension } & \multirow{2}{*}{\multicolumn{2}{|c|}{ PDA plugs (4 mm diameter) }} \\
\hline & \multirow{2}{*}{$\frac{1 \times 10^{6} \mathrm{ml}^{-1}}{\text { Nonwounded }^{\mathrm{x}}}$} & \multirow{2}{*}{$\frac{1 \times 10^{9} \mathrm{ml}^{-1}}{\text { Nonwounded }^{\mathrm{x}}}$} & \multicolumn{2}{|c|}{ PDA plugs (4 mm diameter) } & $1 \times 10^{6} \mathrm{ml}^{-1}$ & $1 \times 10^{9} \mathrm{ml}^{-1}$ & & \\
\hline & & & Nonwounded $^{y}$ & Wounded $^{\mathrm{z}}$ & Nonwounded $^{x}$ & Nonwounded $^{x}$ & Nonwounded ${ }^{y}$ & Wounded $^{\mathbf{z}}$ \\
\hline Check & $\ldots$ & $\ldots$ & $\ldots$ & $\ldots$ & $\ldots$ & $\ldots$ & $\ldots$ & $\ldots$ \\
\hline $\begin{array}{l}\text { C. kahawae } \\
\text { subsp. ciggaro }\end{array}$ & $\ldots$ & $\ldots$ & $18.3 \pm 5.8$ & $31.7 \pm 7.6$ & $\ldots$ & $\ldots$ & $9.5 \pm 1.9 \times 12.0 \pm 2.0$ & $10.6 \pm 0.4 \times 13.1 \pm 0.2$ \\
\hline C. fructicola & $\ldots$ & $\ldots$ & $\ldots$ & $\ldots$ & $\ldots$ & $\ldots$ & $\ldots$ & $\ldots$ \\
\hline C. fioriniae & $81.7 \pm 7.6$ & $100.0 \pm 0.0$ & $70.0 \pm 10.0$ & $91.7 \pm 2.9$ & $4.4 \pm 0.5 \times 5.4 \pm 0.6$ & $10.1 \pm 1.7 \times 13.2 \pm 1.7$ & $12.8 \pm 1.0 \times 15.0 \pm 1.3$ & $16.3 \pm 1.6 \times 19.5 \pm 1.2$ \\
\hline C. karstii & $\ldots$ & $16.7 \pm 2.9$ & $\ldots$ & $28.3 \pm 5.8$ & $\ldots$ & $6.5 \pm 0.6 \times 7.8 \pm 1.1$ & $\ldots$ & $8.1 \pm 1.3 \times 10.0 \pm 1.6$ \\
\hline C. cliviae & $\ldots$ & $\ldots$ & $\ldots$ & $\ldots$ & $\ldots$ & $\ldots$ & $\ldots$ & $\ldots$ \\
\hline C. brevisporum & $3.3 \pm 2.9$ & $43.3 \pm 10.4$ & $\ldots$ & $\ldots$ & $1.3 \pm 1.2 \times 1.7 \pm 1.5$ & $5.4 \pm 0.8 \times 6.7 \pm 0.7$ & $\ldots$ & $\ldots$ \\
\hline
\end{tabular}

${ }^{\mathrm{w}}$ Table shows incidence of disease by percent and lesion diameter following inoculation of wounded and unwounded mulberry leaves. Data represent the mean of three replications, each with 20 leaves on detached twigs. Check = mulberry twigs inoculated with sterile water suspension or PDA plugs without the pathogens (4 mm diameter) (as controls). Ellipsis (...) indicates no symptoms developed on detached leaves.

${ }^{x}$ Unwounded, inoculated with $15 \mu \mathrm{l}$ of conidial suspension.

y Unwounded, inoculated with a 4-mm PDA plug.

z Wounded by sterile pinprick, inoculated with a 4-mm PDA plug.
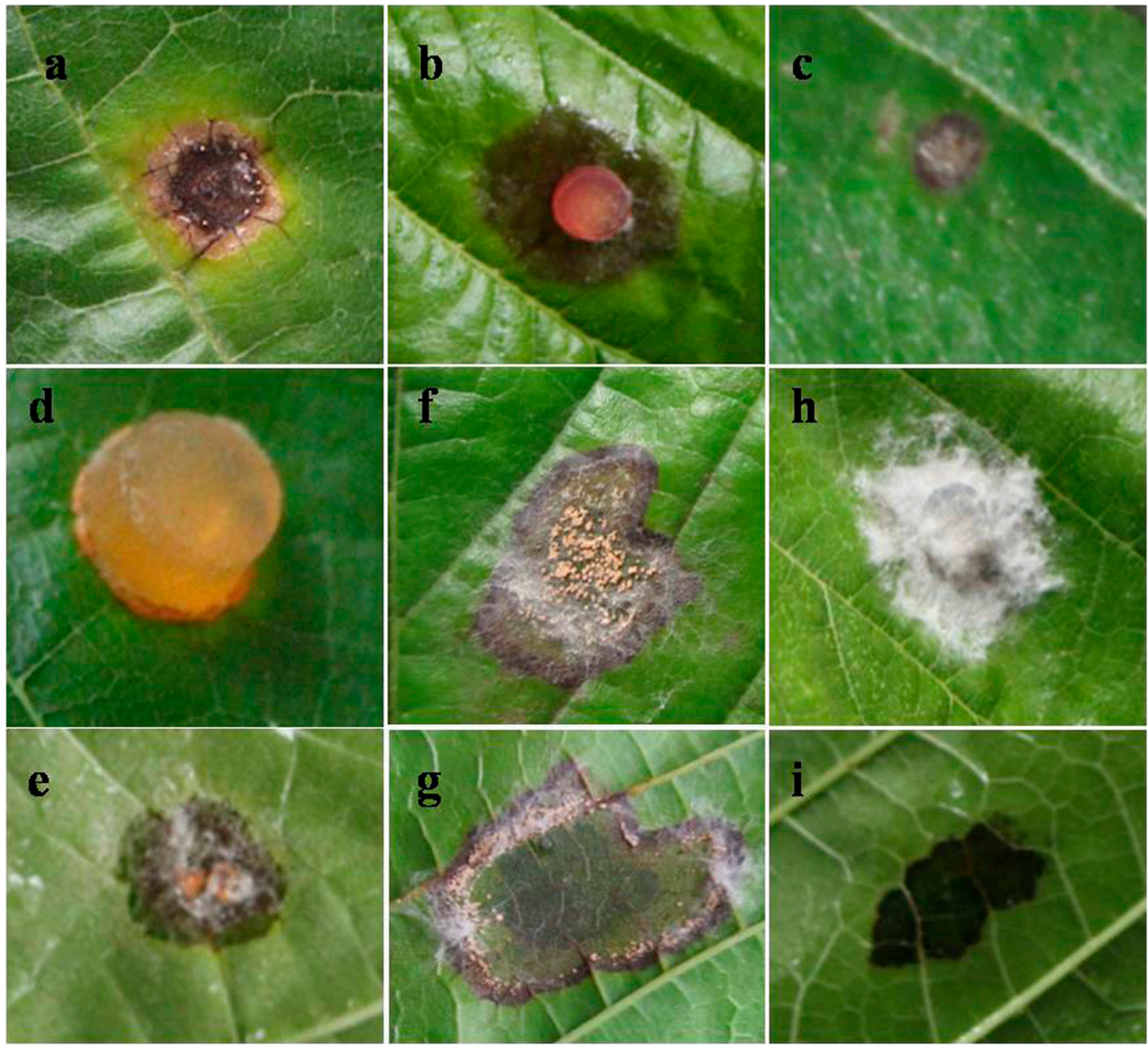

Fig. 5. Symptoms observed in pathogenicity tests on leaves of detached twigs 10 days after inoculation: a, symptoms induced with $10^{6}$ conidial suspension of isolate S22; b, symptoms induced with a 4-mm PDA plug of isolate S22 without wounding; c, symptoms induced with $10^{9}$ conidial suspension of isolate S38; $d$ and e, symptoms induced with a 4-mm PDA plug of isolate S29 with wounding; $\mathbf{f}$ and $\mathbf{g}$, symptoms induced with $10^{9}$ conidial suspension of isolate S29; and $\mathbf{h}$ and $\mathrm{i}$, symptoms induced with a 4-mm PDA plug of isolate $\mathrm{S} 8$ with wounding. 
Additionally, C. fructicola and C. cliviae were reported for the first time as endophytes on mulberry in China. C. dematium, which was once reported to be responsible for mulberry anthracnose in Japan (Yoshida and Shirata 1999), was not found in this study. With the changes of a number of factors such as species, inoculation methods, and conditions, symptoms of inoculation varied considerably (Freeman et al. 1998; Simmonds 1966). Therefore, in order to more accurately reflect the true virulence potential of these species, further research should be conducted to determine the pathogenicity according to natural infections rather than artificial inoculations (Niu et al. 2016; Prihastuti et al. 2009).

Since several decades ago, leaf spots caused by Colletotrichum species had been a common fungal disease on mulberry in several countries, including Japan (Hara 1925, 1954; Kobayashi 2007; Yoshida et al. 1995), India (Mathur 1979), and China (Tai 1979; Tian 1981; Zhang et al. 2011). In this study, we accurately identified six Colletotrichum species isolated from mulberry leaves based on the morphological and molecular characteristics; pathogenicity tests showed that $C$. fioriniae was the most aggressive species. This information is useful for implementing management strategies for mulberry anthracnose in China.

\section{Literature Cited}

Afanador-Kafuri, L., González, A., Gañán, L., Mejía, J. F., Cardona, N., and Alvarez, E. 2014. Characterization of the Colletotrichum species causing anthracnose in Andean blackberry in Colombia. Plant Dis. 98:1503-1513.

Babu, A. M., Chowdary, N. B., Kumar, V., Rajan, M. V., and Dandin, S. B. 2008. Infection process of Colletotrichum dematium on mulberry leaves: An unusual method of sporulation. Arch. Phytopathol. Plant Prot. 41:290-295.

Barbieri, M. C. G., Ciampi-Guillardi, M., Moraes, S. R. G., Bonaldo, S. M., Rogerio, F., Linhares, R. R., and Massola, N. S., Jr. 2017. First report of Colletotrichum cliviae causing anthracnose on soybean in Brazil. Plant Dis. 101:1677.

Baroncelli, R., Sarrocco, S., Zapparata, A., Tavarini, S., Angelini, L. G., and Vannacci, G. 2015. Characterization and epidemiology of Colletotrichum acutatum sensu lato (C. chrysanthemi) causing Carthamus tinctorius anthracnose. Plant Pathol. 64:375-384.

Bezerra, J. P., Ferreira, P. V., Barbosa, L. da F., Ramos-Sobrinho, R., Pinho, D. B., Reis, A., Assunção, I. P., and Lima, G. S. A. 2016. First report of anthracnose on chayote fruits (Sechium edule) caused by Colletotrichum brevisporum. Plant Dis. 100:217.

Bonde, M. R., Nester, S. E., and Berner, D. K. 2012. Effects of daily temperature highs on development of Phakopsora pachyrhizi on soybean. Phytopathology 102:761-768.

Cai, L., Hyde, K. D., Taylor, P. W. J., Weir, B. S., Waller, J. M., Abang, M. M., Zhang, J. Z., Yang, Y. L., Phoulivong, S., Liu, Z. Y., Prihastuti, H., Shivas, R. G., McKenzie, E. H. C., and Johnston, P. R. 2009. A polyphasic approach for studying Colletotrichum. Fungal Divers. 39:183-204.

Cai, L., Udayanga, D., Manamgoda, D. S., Maharachchikumbura, S. S. N., McKenzie, E. H. C., Guo, L. D., Liu, X. Z., Bahkali, A. H., and Hyde, K. D. 2011. The need to carry out re-inventory of plant pathogenic fungi. Trop. Plant Pathol. 36:205-213.

Cai, M., Mu, L., Wang, Z. L., Liu, J. Y., Liu, T. L., Wanapat, M., and Huang, B. Z. 2019. Assessment of mulberry leaf as a potential feed supplement for animal feeding in P.R. China. Asian-Australas. J. Anim. Sci. 32:1145-1152.

Cai, Z. Y., Liu, Y. X., Shi, Y. P., Mu, H. J., and Li, G. H. 2016. First report of leaf anthracnose caused by Colletotrichum karstii of rubber tree in China. Plant Dis. 100:2528.

Cannon, P. F., Bridge, P. D., and Monte, E. 2000. Linking the past, present, and future of Colletotrichum systematics. Pages 1-20 in: Colletotrichum: Host Specificity, Pathology, and Host-Pathogen Interaction. D. Prusky, S. Freeman, and M. Dickman, eds. APS Press, St. Paul, MN.

Cannon, P. F., Damm, U., Johnston, P. R., and Weir, B. S. 2012. Colletotrichum - Current status and future directions. Stud. Mycol. 73:181-213.

Chang, L. W., Juang, L. J., Wang, B. S., Wang, M. Y., Tai, H. M., Hung, W. J., Chen, Y. J., and Huang, M. H. 2011. Antioxidant and antityrosinase activity of mulberry (Morus alba L.) twigs and root bark. Food Chem. Toxicol. 49: 785-790.

Chen, Y., Qiao, W., Zeng, L., Shen, D., Liu, Z., Wang, X., and Tong, H. 2017. Characterization, pathogenicity, and phylogenetic analyses of Colletotrichum species associated with brown blight disease on Camellia sinensis in China. Plant Dis. 101:1022-1028.

Costa, J. F. O., Ramos-Sobrinho, R., Chaves, T. P., Silva, J. R. A., Pinho, D. B., Assunção, I. P., and Lima, G. S. A. 2017. First report of Colletotrichum fructicola causing anthracnose on Annona leaves in Brazil. Plant Dis. 101:386.

Damm, U., Cannon, P. F., Woudenberg, J. H. C., and Crous, P. W. 2012a. The Colletotrichum acutatum species complex. Stud. Mycol. 73:37-113.
Damm, U., Cannon, P. F., Woudenberg, J. H. C., Johnston, P. R., Weir, B. S., Tan, Y. P., Shivas, R. G., and Crous, P. W. 2012b. The Colletotrichum boninense species complex. Stud. Mycol. 73:1-36.

Damm, U., Woudenberg, J. H. C., Cannon, P. F., and Crous, P. W. 2009 Colletotrichum species with curved conidia from herbaceous hosts. Fungal Divers. 39:45-87

Diao, Y. Z., Zhang, C., Liu, F., Wang, W. Z., Liu, L., Cai, L., and Liu, X. L. 2017. Colletotrichum species causing anthracnose disease of chili in China. Persoonia 38:20-37

Dillard, C. J., and German, J. B. 2000. Phytochemicals: Nutraceuticals and human health. J. Sci. Food Agric. 80:1744-1756.

Du, Y. X., Shi, N. N., Chen, W. L., Ruan, H. C., Yang, X. J., Gan, L., Dai, Y. L. and Chen, F. R. 2017. Identification of Colletotrichum brevisporum causing anthracnose on passion fruit. Can. J. Plant Pathol. 39:527-532.

Faedda, R., Agosteo, G. E., Schena, L., Mosca, S., Frisullo, S., Magnano di San Lio, G., and Cacciola, S. O. 2011. Colletotrichum clavatum sp. nov. identified as the causal agent of olive anthracnose in Italy. Phytopathol. Mediterr. 50:283-302

Fan, Z., Wang, N., Zhu, L., Zou, D., Shi, X., Yu, Z., and Guo, G. 2016. Effects of processing technological conditions on 1-deoxynojirimycin content in mulberry leaf tea. Sci. Seric. 42:1062-1067.

Freeman, S., Katan, T., and Shabi, E. 1998. Characterization of Colletotrichum species responsible for anthracnose diseases of various fruits. Plant Dis. 82: 596-605.

Garibaldi, A., Gilardi, G., Puglisi, I., Cacciola, S. O., and Gullino, M. L. 2016. First report of leaf spot caused by Colletotrichum kahawae on cultivated rocket (Eruca sativa) in Italy. Plant Dis. 100:1240.

Han, Y. C., Zeng, X. G., Xiang, F. Y., Ren, L., Chen, F. Y., and Gu, Y. C. 2016 Distribution and characteristics of Colletotrichum spp. associated with anthracnose of strawberry in Hubei, China. Plant Dis. 100:996-1006.

Hara, K. 1925. Pages 148-149 in: Pathology of Practical Crops. Youkendo, Tokyo, Japan.

Hara, K. 1954. Page 400 in: The Catalog of Fungi in Japan. The Mycological Society of Japan, Gifu, Japan.

Huang, F., Chen, G. Q., Hou, X., Fu, Y. S., Cai, L., Hyde, K. D., and Li, H. Y. 2013. Colletotrichum species associated with cultivated citrus in China Fungal Divers. 61:61-74.

Jayawardena, R. S., Hyde, K. D., Damm, U., Cai, L., Liu, M., Li, X. H., Zhang, W., Zhao, W. S., and Yan, J. Y. 2016. Notes on currently accepted species of Colletotrichum. Mycosphere. 7:1192-1260.

Jia, Y. X., Yang, M. X., Wang, H., Luo, L. J., Chen, Z. J., Yu, D. G., and Bai, C. J. 2017. First report of anthracnose on Stylosanthes guianensis caused by Colletotrichum karstii in China. Plant Dis. 101:630.

Jia, Z., Tang, M., and Wu, J. 1999. The determination of flavonoid contents in mulberry and their scavenging effects in superoxide radicals. Food Chem. 64: $555-559$.

Kobayashi, T. 2007. Index of Fungi Inhabiting Woody Plants in Japan. ZenkokuNoson-Kyoiku Kyokai Publishing, Tokyo, Japan.

Li, Y. L., Zhou, Z., and Yan, Z. B. 2018. First report of Colletotrichum karstii causing anthracnose on Nandina domestica in Henan Province, China. Plant Dis. 102:444

Liu, F., Damm, U., Cai, L., and Crous, P. W. 2013. Species of the Colletotrichum gloeosporioides complex associated with anthracnose diseases of Proteacea. Fungal Divers. 61:89-105.

Liu, F., Tang, G., Zheng, X., Li, Y., Sun, X., Qi, X., Zhou, Y., Xu, Z., Chen, X., Chang, X., Zhang, S., and Gong, G. 2016a. Molecular and phenotypic characterization of Colletotrichum species associated with anthracnose disease in peppers from Sichuan Province, China. Sci. Rep. 6:32761.

Liu, L. P., Yang, L. Y., Liu, Y. N., Yang, L. N., Lu, B. H., Yu, L., Jin, X. S., Wang, X., Yang, C., Li, Y., and Gao, J. 2016b. First report of anthracnose disease caused by Colletotrichum fioriniae on barbary wolfberry in China. Plant Dis. 100:2534.

Mathur, R. S. 1979. The Coelomycetes of India. BishenSingh Mahendra Pal Singh, Delhi, India.

Niu, X., Gao, H., Qi, J., Chen, M., Tao, A., Xu, J., Dai, Z., and Su, J. 2016 Colletotrichum species associated with jute (Corchorus capsularis L.) anthracnose in southeastern China. Sci. Rep. 6:25179.

O'Connell, R. J., Thon, M. R., Hacquard, S., Amyotte, S. G., Kleemann, J., Torres, M. F., Damm, U., Buiate, E. A., Epstein, L., and Alkan, N. 2012. Lifestyle transitions in plant pathogenic Colletotrichum fungi deciphered by genome and transcriptome analyses. Nat. Genet. 44:1060.

Paul, N. C., Lee, H. B., Lee, J. H., Shin, K. S., Ryu, T. H., Kwon, H. R., Kim, Y. K., Youn, Y. N., and Yu, S. H. 2014. Endophytic fungi from Lycium chinense Mill and characterization of two new Korean records of Colletotrichum. Int. J. Mol. Sci. 15:15272-15286.

Peng, L. J., Tang, Y. L., Hyde, K. D., Bahkali, A. H., and Liu, Z. Y. 2012 Colletotrichum species on Citrus leaves in Guizhou and Yunnan Provinces, China. Cryptogam., Mycol. 33:267-283.

Prihastuti, H., Cai, L., Chen, H., McKenzie, E. H. C., and Hyde, K. D. 2009 Characterization of Colletotrichum species associated with coffee berries in northern Thailand. Fungal Divers. 39:89-109.

Rayner, R. W. 1970. A Mycological Colour Chart. Commonwealth Mycological Institute, Kew, U.K. 
Rojas, E. I., Rehner, S. A., Samuels, G. J., Van Bael, S. A., Herre, E. A., Cannon, P., Chen, R., Pang, J., Wang, R., Zhang, Y., Peng, Y. Q., and Sha, T. 2010. Colletotrichum gloeosporioides s.l. associated with Theobroma cacao and other plants in Panama: Multilocus phylogenies distinguish host-associated pathogens from asymptomatic endophytes. Mycologia 102:1318-1338.

Saini, T. J., Gupta, S. G., and Anandalakshmi, R. 2017. Detection of chili anthracnose caused by Colletotrichum cliviae in India. Australas. Plant Dis. Notes 12:33

Scandiani, M. M., Ruberti, D. S., Giorda, L. M., Pioli, R. N., Luque, A. G., Bottai, H., Ivancovich, J. J., Aoki, T., and O'Donnell, K. 2011. Comparison of inoculation methods for characterizing relative aggressiveness of two soybean sudden-death syndrome pathogens, Fusarium virguliforme and F. tucumaniae. Trop. Plant Pathol. 36:133-140.

Schena, L., Mosca, S., Cacciola, S. O., Faedda, R., Sanzani, S. M., Agosteo, G. E., Sergeeva, V., and Magnano di San Lio, G. 2014. Species of the Colletotrichum gloeosporioides and $C$. boninense complexes associated with olive anthracnose. Plant Pathol. 63:437-446.

Simmonds, J. H. 1966. A study of the species of Colletotrichum causing ripe fruit rots in Queensland. Queensl. J. Agric. Anim. Sci 22:437-459.

Singab, A. N. B., El-Beshbishy, H. A., Yonekawa, M., Nomura, T., and Fukai, T. 2005. Hypoglycemic effect of Egyptian Morus alba root bark extract: Effect on diabetes and lipid peroxidation of streptozotocin-induced diabetic rats. J. Ethnopharmacol. 100:333-338.

Song, W., Wang, H. J., Bucheli, P., Zhang, P. F., Wei, D. Z., and Lu, Y. H. 2009. Phytochemical profiles of different mulberry (Morus sp.) species from China. J. Agric. Food Chem. 57:9133-9140.

Sun, W., Su, Y. Y., Cai, L., Sun, W., and Sha, W. 2012. First report of leaf disease on Cinnamomum subavenium caused by Colletotrichum fioriniae in China. Plant Dis. 96:143.

Tai, F. L. 1979. Sylloge Fungorum Sinicorum. Science Press, Academia Sinica, Peking, China.

Tamura, K., Stecher, G., Peterson, D., Filipski, A., and Kumar, S. 2013. MEGA6: Molecular Evolutionary Genetics Analysis version 6.0. Mol. Biol. Evol. 30: 2725-2729.

Tao, G., Liu, Z. Y., Liu, F., Gao, Y. H., and Cai, L. 2013. Endophytic Colletotrichum species from Bletilla ochracea (Orchidaceae), with descriptions of seven new species. Fungal Divers. 61:139-164.

Than, P. P., Jeewon, R., Hyde, K. D., Pongsupasamit, S., Mongkolporn, O., and Taylor, P. W. J. 2008. Characterization and pathogenicity of Colletotrichum species associated with anthracnose on chilli (Capsicum spp.) in Thailand. Plant Pathol. 57:562-572.

Tian, L. D. 1981. Study on pathogen and pathogenesis of anthracnose on Morus alba. Sci. Seric. 7:15-20.

Tsuduki, T., Kikuchi, I., Kimura, T., Nakagawa, K., and Miyazawa, T. 2013 Intake of mulberry 1-deoxynojirimycin prevents diet-induced obesity through increases in adiponectin in mice. Food Chem. 139:16-23.

von Arx, J. A. 1957. Die Arten der Gattung Colletotrichum. Phytopathol. Z. 29: 413-468.

Waller, J. M., Bridge, P. D., Black, R., and Hakiza, G. 1993. Characterization of the coffee berry disease pathogen, Colletotrichum kahawae sp. nov. Mycol. Res. 97:989-994.

Weir, B. S., Johnston, P. R., and Damm, U. 2012. The Colletotrichum gloeosporioides species complex. Stud. Mycol. 73:115-180.

Xue, L. H., Liu, Y., Li, C. J., Zhang, L., and Huang, X. Q. 2017. First report of Colletotrichum fioriniae causing anthracnose on Ficus virens in China. Plant Dis. 101:1044.

Yang, Y. L., Liu, Z. Y., Cai, L., Hyde, K. D., Yu, Z. N., and McKenzie, E. H. C. 2009. Colletotrichum anthracnose of Amaryllidaceae. Fungal Divers. 39: 123-146.

Yoshida, S., and Shirata, A. 1998. Annual development of mulberry anthracnose caused by Colletotrichum dematium in relation to position of leaves in tree. $\mathbf{J}$. Sericultural Sci. Jpn. 67:327-332.

Yoshida, S., and Shirata, A. 1999. Survival of Colletotrichum dematium in soil and infected mulberry leaves. Plant Dis. 83:465-468.

Yoshida, S., Shirata, A., and Hiradate, S. 2002. Ecological characteristics and biological control of mulberry anthracnose. Jpn. Agric. Res. Q. 36:89-95.

Yoshida, S., Shirata, A., Yoshida, S., and Kobayashi, T. 1995. Anthracnose fungi, Colletotrichum dematium, C. acutatum, Glomerellac ingulata isolated from diseased mulberry leaves and their pathogenicity. Ann. Phytopathol. Soc. Jpn. 61:75-81.

Zhang, Z. Y., Yang, H. Y., Zheng, X. L., Zeng, X. X., and Wang, Y. Y. 2011. Two species of Colletotrichum in China-VI. Pages 138-139 in: Proceedings of the Annual Meeting of Chinese Society for Plant Pathology.

Zhou, Z., and Li, Y. L. 2017. First report of Colletotrichum cliviae causing anthracnose on Zamioculcas zamiifolia in Henan Province, China. Plant Dis. 101:838.

Zhu, Y. Z., Liao, W. J., Zou, D. X., Wu, Y. J., and Zhou, Y. 2015. First report of leaf spot disease on walnut caused by Colletotrichum fioriniae in China. Plant Dis. 99:289. 